\author{
Anna JACH (D) \\ Jagiellonian University in Kraków \\ anna.jach@uj.edu.pl
}

\title{
THEORETICAL APPROACHES IN THE STUDY OF THE NON-GOVERNMENTAL, NON-COMMERCIAL SECTOR IN MODERN RUSSIA ${ }^{1}$
}

ABSTRACT As part of a political system constituted by individuals and social groups, due to its pro publico bono activities, the non-governmental, non-commercial sector (also known as institutions of civil society) is usually referred to by different terms, both in foreign (English) and Russian languages. Since the Russian nongovernmental, non-commercial sector (некоммерческая неправительственная организация) is not identical to its Western variants, it exhibits a number of differences, the sources of which are both exogenous and endogenous conditions. The issue of the specificities of the non-governmental, non-commercial sector can be researched through a system analysis. The theoretical context for this method creates a new institutionalism, also called neo-institutionalism. In turn, the institutional analysis refers to such theories as systemic change and neo-corporatism as well as the theory of participation or political participation. What turned out to be indispensable were the models defining the conceptual framework for such phenomena as group theory - interest/pressure, or metapolitics, but with regard to its civil forms of participation. The abovementioned methods and stances prove the complexity of the presented subject - the multifaceted nature of the problem, where the exploratory field requires referring to research techniques and tools from many related disciplines. The issue of the non-gov-

\footnotetext{
This article is a shortened version of a fragment focusing on theoretical approaches in the process of researching the non-governmental, non-commercial sector in contemporary Russia, published in the work Pozarzadowy sektor niekomercyjny w Rosji 2000-2018. Osobliwości funkcjonowania. The Non-Governmental, Non-Commercial Sector in Russia in 2000-2018. Peculiarities of Functioning. Heправительственный некоммерческий сектор в России в 2000-2018 г2. Особенности функционирования, Kraków 2019.
} 
ernmental, non-commercial sector in contemporary Russia should be perceived as a specific phenomenon, primarily because this sector is developing, no matter what transformations of an internal nature occur. Its exploration requires using such theoretical approaches that will allow its mechanisms to be defined. Such an approach must include the specifics of the society and the state within which the social sector develops. Therefore the presentation of theoretical premises applied in research on non-governmental, non-commercial sector in today's Russia is the first step in diagnosing the phenomenon of the functioning of a non-governmental, non-commercial sector in the conditions of an authoritarian state.

Key words: Russia, non-governmental, non-commercial sector, system analysis, neo-corporatist approach, neo-institutional analysis

$\mathrm{T}$

he main objective of the study is to present the specificity of the Russian nongovernmental, non-commercial sector as a phenomenon of trialistic provenance in the context of a state undergoing the process of transformation without a clearly defined vector. The transformation, which has continued for over 30 years, has been accompanied by the assumption that all aspects of the citizens' socio-political and private lives should be controlled. This has been a constant tendency perpetuated by past experience, never questioned by anyone before, even in the "time of troubles" in the 1990s. ${ }^{2}$

Apart from European (French, German, Italian and Swedish) tradition of bottomup social activity of institutions from the non-governmental, non-commercial sector, ${ }^{3}$ the most widespread concept of the non-governmental sector is the classic definition of non-profit organizations and the non-commercial sector, which reflects the American tradition of understanding the third sector. However, since this can also be applied to Russian reality, referring to this definition is fully justified. According to it, the nongovernmental, non-commercial sector is made up of organizations which a) are formal or unofficial, which means that they are institutionalized to some extent, and that, in general, they have legal personality; b) are private institutions, that is, separate from the state and organizations directly related to the government; $c$ ) are independent in the sense that they themselves must determine their own rules and authorities competent to make decisions; d) cannot distribute profit to their members and management; e) involve volunteers and donors in their activities, and their membership is voluntary. ${ }^{4}$

The experiences of the Russian third sector are not a very faithful copy of European solutions, but were implemented much later due to the specificity of the socio-economic

2 A. Skrzypek, Druga smuta. Zarys dziejów Rosji 1985-2004, Warszawa 2004.

3 H. Anheier, S. Mertens, “Sektor non profit w perspektywie międzynarodowej i europejskiej: dane, teoria i statystyka”, in A. Gałązka, J. Herbst (eds.), Trzeci sektor dla zaawansowanych. Wspótczesne teorie trzeciego sektora. Wybór tekstów, transl. by J. Popowski, Warszawa 2006, p. 72.

4 J. Defourny, P. Develtere, "Ekonomia społeczna: ogólnoświatowy trzeci sektor", in A. Gałązka, J. Herbst (eds.), Trzeci sektor dla zaawansowanych..., pp. 27-28. 
development of the society and internal political conditions. The concept of a nongovernmental, non-commercial sector understood through the prism of economics, and hence the efficiency and effectiveness of state management, became a strategy element only as a result of the long-term, adverse consequences of both economic crises $(1998,2008)$, which shook the socio-economic foundations of the state. These circumstances resulted in a shift towards European traditions; however, such practices had existed in Russia at earlier stages of its statehood. The change of management direction from state to socio-state was the consequence of the decision makers defining key areas of activity in which the sector's initiative was not only desirable but even indispensable. These areas were included in the category of socially oriented non-profit organizations (социально ориентированные некоммерческие организации - СО НКО). Within their framework, the institutions which formed this socially-oriented, non-commercial sector, such as consumers' cooperatives, associations, mutual societies and social foundations, particularly those of a regional and local nature, became "social enterprises" (социальные предпринимательства), acting rather for the benefit of their members or wider communities than for maximizing investors' profits. In this perspective, the social impact of such enterprises (which are usually non-profit organizations) on society is not only a consequence or a side effect of their business, but also their motivation in itself. 5

Organizations oriented towards social activity have found themselves in a group of privileged - and thus state-supported - institutions, since by fulfilling service functions for the public or their own members, they create a space for voluntary work. In turn, advocacy organizations are in a different position, being the voice of the civil society towards the institutions of power. They create a public space for active voluntary action and, because they maintain some degree of autonomy and provide services aimed at unblocking the "channel of influence", they are often perceived by the authorities as "hostile".

The peculiarity of the organization of Russian social reality determines the discrepancy between the environmental needs of the citizens and the formally designed institutional structure established to meet these needs. The essence of this discrepancy reflects the basic contradictions characterizing the relationship between power and society in Russia. Within it, there were visible tendencies on both sides to selectively apply the law and restore state control over institutions that "escaped" it. The key of the program was the modernization announced in 2000, which in fact meant the stabilization of the power structure through its centralization, and not - as it had been expected - by democratization. ${ }^{7}$

The specific way in which the non-commercial, non-governmental sector in Russia functions in the $21^{\text {st }}$ century is directly related to such phenomena as "typicality"

5 M. Nyssens, "The Third Sector and the Social Inclusion Agenda. The Role of Social Enterprises in the Field of Work Integration", in S.P. Osborne (ed.), The Third Sector in Europe. Prospects and Challenges, London-New York 2008, p. 88.

6 M. Kiviniemi, "Conclusions. The State of Our Knowledge and Future Challenges", in S.P. Osborne (ed.), The Third Sector in Europe..., p. 360.

A. Skrzypek, Putinada. Rosja - kraj kierowanej demokracji, Warszawa 2014, p. 104. 
and "peculiarity", which - when considering the world with regard to order, normality, familiarity, chaos, anomaly and strangeness - emphasize "obviousness", "ordinariness" and "peculiarities" which exist in them. ${ }^{8}$

Assuming that the third sector organizations, being one of the key elements of a political system, are subject to the same transformations as the society and the system itself, ${ }^{9}$ there is a logical justification to the idea of including them in the concept of four dimensions of social structures when referring to the above categories of differences. This can not only be used to indicate the specificity of normative structures of social life (rules of action), collective or social consciousness (beliefs, views), access to resources and specific goods as a result of social interests (privileges and disabilities) or mutual interactions between entities, but above all it can be used to diagnose what these "peculiarities" and "ordinariness" constituting an immanent part of the social system really are. ${ }^{10}$

Assuming that the Russian non-governmental, non-commercial sector is made up of social structures that can be described with such theoretical concepts as "social organization" - "non-profit organization" - "non-commercial organization" - "non-governmental organization" - "third-sector organization" - "organization of the non-governmental sector", it can be said that they describe an organization which: 1. is not part of the state apparatus, even if it can receive support from government sources; 2 . will not, according to the law, distribute its profit to the owners or other persons controlling the organization, i.e. members, shareholders, founders, employees or members of the management bodies (non-distribution constraint); 3 . has a structure and displays regular activities, regardless of whether it is formalized and has a statute, or is an informal association, or is registered in accordance with the law; 4 . has voluntary membership; 5. does not strive for power; 6 . is self-governing; 7. has joint authority; 8. allocates possible surpluses to statutory purposes (a not-for-profit organization). ${ }^{11}$

The above operational-structural definition developed during international research on the non-commercial sector should be supplemented with a functional approach which points to the division of tasks in a society between various organizational forms, assuming the three-sectoral definition of a state. ${ }^{12}$ It is the state's trialistic concept together with the principles of constitutional law, the law of preferences, and the law of commercial activity which implies that the boundaries between the state, the commercial, and non-governmental sectors influence the division of tasks. What binds

8 J. Łotman, B. Uspienski, “'Odszczepieniec' i 'odszczepieństwo' jako pozycje społeczno-psychologiczne w kulturze rosyjskiej - na materiale z epoki przedpiotrowej ('Swoje' i 'obce' w historii kultury rosyjskiej)", in B. Żyłko (ed.), Semiotyka dziejów Rosji, transl. by B. Żyłko, Łódź 1993, pp. 62-77; Z. Bauman, Ponowoczesność jako źródto cierpień, Warszawa 2000, pp. 11-34; M. Douglas, Czystość i zmaza. Analiza pojęć nieczystości i tabu, transl. by M. Bucholc, Warszawa 2007.

$9 \quad$ W. Gumuła, Teoria osobliwości spotecznych. Zaskakująca transformacja w Polsce, Warszawa 2008, p. 18.

10 P. Sztompka, Socjologia. Analiza spoteczeństwa, Kraków 2012, pp. 174-175.

11 L.M. Salamon, W.S. Sokolowski, R. List, Global Civil Society. An Overview, Baltimore 2003, pp. 7-8.

12 J.G. Simon, "Foreword", in D.R. Young, If Not for Profit, for What? A Behavioral Theory of the Nonprofit Sector Based on Entrepreneurship, Lexington 1983. 
the above regulations is the law of state supervision, whose presence is crucial since it is a mechanism that can ensure the effectiveness of any type of public law regulating the third sector. ${ }^{13}$

Such an understanding of the functionality of the non-governmental, non-commercial sector is followed by an analysis of institutionalized civil initiatives that have no intention of gaining power or participating in a political game, but which exist, firstly, to solve social problems that the state cannot solve or does not solve, and secondly, to introduce such an interpretation of the social world into the public discourse that is close to all members of a given non-governmental organization. On this ground, the assertion that grassroots civil society, manifested as the non-governmental, noncommercial sector, will indispensably emerge, means consent to the functioning of the voluntary self-organization of members of the society in Russia, who organize themselves and associate in order to realize and meet their common needs and interests. ${ }^{14} \mathrm{In}$ this view, if state power is a tool of leadership (control) over society, a tool characterized by trust in a special institutionalized and legal apparatus of coercion, then on the one hand it is a self-organizing system with horizontal social ties between members of society, and on the other hand it is a hierarchical system with vertical social connections. Such a formulation of the semantic field of civil society facilitates a deeper reflection on its functionality in the conditions of a transforming state with no vector of transformations eventually oriented either towards polyarchy or authoritarianism. The peculiarities of the functioning of the civil society in the conditions of an authoritarian state, which contemporary Russia undoubtedly is, thus reveal not only the peculiarities of the political system but also the uniqueness of the non-governmental, non-commercial sector.

The issue of the peculiarities of the non-governmental, non-commercial sector can be researched through system analysis. The theoretical context for this method creates a new institutionalism, also called neo-institutionalism. In turn, the institutional analysis refers to such theories as systemic change and neo-corporatism as well as the theory of political participation. What turned out to be indispensable were the models defining the conceptual framework for such phenomena as group theory - interest/pressure, or metapolitics, but with regard to its civil forms of participation. The abovementioned methods and stances prove the complexity of the presented subject - the multifaceted nature of the problem, the exploratory field of which requires referring to research techniques and tools from many related disciplines.

The theoretical current that constitutes the basis for analyzing the peculiarities of the functioning of the non-governmental, non-commercial sector, understood as a separate social subsystem within the political system in Russia in the years 2000-2018 is the neo-institutional direction. ${ }^{15}$ Within the framework of this current, a convenient

13 M. Kisilowski, Prawo sektora pozarzadowego. Analiza funkcjonalna, Warszawa 2009, pp. 33, 36-40.

14 “Выступление на открытии Гражданского форума”, Президент России, 21 November 2001, at <http://kremlin.ru/events/president/transcripts/21408>.

15 J.G. March, J.P. Olsen, “The New Institutionalism: Organizational Factors in Political Life”, American 
tool for researching proceedings is system analysis. Since a political system is understood as an organization of elements having a specific structure, internally organized into one composition, it can be treated as a synergy of interacting elements that are a single, target-oriented system. ${ }^{16}$ These elements that constitute the system are characterized by the presence of specific attributes that come into specific relationships. This facilitated sketching a study on the role of the non-governmental, non-commercial system as one of the main factors shaping the model of state governance.

The system method can be fully applied to the study on functions performed by all three sectors with regard to the implementation of public policy strategies; however, it is worth emphasizing that the third element here (together with the state and the social sector), is not the business, but experts. Obviously, what is meant here is not an elimination of the second (private) sector from the concept of the functioning of a state, but rather a modification of its assumptions. Together with the three sectors - the first (state), the second (commercial), and the third (social) - the expert sector is comparable with the other segments of the modern Russian state in the $21^{\text {st }}$ century. When explaining the issue of three-sector synergy in the field of cooperation for modern socio-political management, Russian researchers justify the need to include a group of specialists in the structure shaping Russian reality with pragmatic reasons. By using the system-functional approach, they focus in this case on the concept of "inputs" and "outputs" of the system, and on this basis, rightly analyze the process of participation of the non-governmental, non-commercial sector in the broadly understood decision-making process of the state. Confirmed in practice, this approach, on the one hand, proves the courage and determination of social activists involved in the activities of numerous social associations and demonstrates the effectiveness of their lobbying and influence in the field, but on the other hand, what it reveals are rather the claims and hopes of the representatives of the intellectual middle class from urban university centers to become a partner for the authorities. This aspect of socio-political life also needed to be included in the research process; what was used to diagnose it was not only the system method but also the historical method since the sources of these social expectations come from both the perestroika and the Yeltsin era. ${ }^{17}$ The exemplification of forms of the self-organization of academic communities (from which the institutions come) which associate experts-mediators are the so-called "think tanks" and

Political Science Review, vol. 78, no. 3 (1984), pp. 734-749; P.A. Hall, R.C.R. Taylor, "Political Science and Three New Institutionalisms", Political Studies, vol. 44, no. 4 (1996), pp. 936-967, at <https:// www.mpifg.de/pu/mpifg_dp/dp96-6.pdf>; A. Antoszewski, "System polityczny jako przedmiot badań politologii i nauki prawa konstytucyjnego", Wroctawskie Studia Erazmiańskie. Studia Erasmiana Wratislaviensia, vol. 8: Rozprawa o metodzie prawa i polityki. Discourse on the Methods of Law and Politics (2014), pp. 19-20.

16 A. Antoszewski, “System polityczny..., p. 20.

17 А.Ю. Сунгуров, “Публичная политика: основные направления исследований (мировой и российский опыт)", Публичнал политика, nо. 1 (2017), pp. 8-28; A. Sungurow, "Rosyjskie i radzieckie tradycje udziału przedstawicieli środowiska akademickiego w polityce. Władimir Wiernadski, Andriej Sacharow i inni", in A. Jach (ed.), Rewolucja rosyjska. Spuścizna. "Implementacje strategii" zmiany, Kraków 2017, pp. 81-90. 
professional consulting associations, whose activity confirms the thesis about the permanent fluctuation of Russian society, regardless of the current vector of internal policy and the political regime. ${ }^{18}$

The analysis of the peculiarities of the non-governmental, non-commercial sector would be incomplete without referring to the conceptual framework of the systemic change theory, which is an interesting step in the context of the strategy of modernizing the state in the spirit of the challenges of the $21^{\text {st }}$ century, announced in 2000 in Russia by the new Kremlin ruler Vladimir Putin. The concept of modernization is defined as a multifaceted process of transition from traditional to modern society, ${ }^{19}$ which takes place at the socio-economic, cultural, and political levels, using instruments such as: industrialization, urbanization, education, technological, and organizational progress. However, it is worth noting that this concept was understood differently in modernizing Russia. ${ }^{20}$ The goal of the new ruling elite was not to realize the postulates of modernization, but to fossilize the existing reality while strengthening the executive power. The centralization of the state management structure resulted in the introduction of political stabilization of the elites and social groups associated with the president security services, siloviks, and economy departments of strategic importance for the state. This resulted in the strengthening of the vertical structure of power (вертикаль власти), which de facto became a backbone for a strong model of presidential power in an almost unchanged form. On the other hand, departure from the previously declared and still upheld democratization tendencies turned into devising Russia's own conception of the development of democracy - a sovereign democracy (суверенная демократия). ${ }^{21}$

The inefficiency of state structures and the inability to overcome the stagnation in which Russia found itself forced the policy-makers to change their strategy towards the other two sectors. This led to the initiation of constructive preparations to create a new concept of management, which was to be based on three-sector cooperation: the state, the world of business, and civil society.

However, what becomes visible here is the constant feature of Russian internal policy - the tradition of referring to the concepts, strategies, experiences, practices, and programs existing in the West and their implementation in Russia. That was also the case here. The change in the strategy of management was interpreted through the concept of public policy, which, while closely related to the political system, comes down to the organized activity of political actors (political parties, civil associations, government, etc.) aimed at solving social problems in particular ways. This, in turn, is a direct

18 А.Ю. Сунгуров, Как возникают политические инновачии: “Фабрики мысли” и другие институmы-медиаторы, Москва 2015.

19 A.W. Jabłoński, “Teoria i podejścia w badaniach zmiany systemów politycznych”, in B. Krauz-Mozer, P. Ścigaj (eds.), Podejścia badawcze i metodologie w nauce o polityce, Kraków 2013, pp. 78-86.

20 R.A. Dahl, B. Stinebrickner, Wspótczesna analiza polityczna, transl. by P.M. Kazimierczak, Warszawa 2007, p. 151.

21 В.Ю. Сурков, “Национализация будущего [парагрвфы рго суверенную демократию]”, in Cуверенная демократия. От идеи к доктрине. Сборник статей, Москва 2007, pp. 27-44. 
reference to another approach - neo-corporatism, which, by situating the Russian nongovernmental, non-commercial sector in the theory of civil society, allows its functionality to be studied.22

In other words, all political actors representing particular sectors are treated as "corporations" striving to gain access to the decision-making process. The process of policymakers granting a privileged position to specific social groups and the interest groups which represent them results in the development of an institutionalized system of links between interest groups and the government. The parties strive to develop stable mechanisms and procedures of cooperation in the process of creating and implementing public policy. The concentration becomes expressed through the creation of a closed form of conducting political negotiations referred to as tripartism. This is a configuration of institutions and agencies representing the government, the trade unions, and the nongovernmental, non-commercial sector and entrepreneurs, within which consultations and negotiations are carried out, particularly these concerning the socio-economic policy of the state (e.g. issues of wages, prices, insurance, benefits, and income policy). ${ }^{23}$

Referring to the concept of tripartism and its application in the theory of public policy, as well as the neo-corporatist approach in contemporary Russia, proves effective both at the level of international cooperation and that of internal policy. The adaptation of its assumptions and the implementation of its solutions in Russia by the policy-makers began to stimulate various spheres of social, economic, and political life of the state, actually turning into a dynamic process of recovery, visible particularly among the citizens. The citizens, motivated by a variety of incentives to engage in the modernization processes and increase the functionality and efficiency of the state's structures (primarily at the local level), started to demand with increasing determination that the policy-makers at various levels treat them like partners. In turn, the state authorities made sure, for their own benefit, that the citizens would form grassroots organizations or participate in the top-down organizations founded by the state sector. From the point of view of the policymakers, such subjects were definitely easier to control. In addition, following the principle of competitiveness, they instigated competition between individual social groups regarding the provision of social services and the performance of outsourced tasks. These privileged non-governmental, non-commercial organizations in the end comprised the socially-oriented non-commercial organizations - CO HKO [SO NKO]. In return for fulfilling pro-social functions and de facto substituting the state, these non-profit organizations were granted numerous privileges and support of various authorities.

One of the concepts that finds application in the explanatory process of the peculiarities of the non-governmental, non-commercial sector is undoubtedly the group theory, also called the theory of social groups or the theory of society. Although in this study it does not constitute the main research instrument, referring to it in the case of

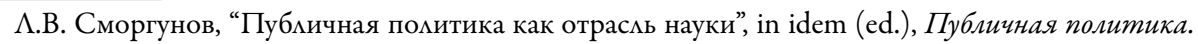
Институть, иифрование, развитие, Москва 2018, p. 15.

23 R. Croucher, G. Wood, "Tripartism in Comparative and Historical Perspective”, Business History, vol. 57, no. 3 (2015), p. 350. 
Russian reality is fully justified. Strong associations of the group theory - particularly with regard to interest groups and influence (pressure) - with the neo-corporative concept indicate its viability and high popularity in countries with less strongly internalized democratic values. Describing the non-governmental organizations of the noncommercial sector as corporate social interest and/or pressure groups allows Russian policy-makers to develop such a political strategy in the field of state governance that, as a result of synergy, can bring the effects desired by the government. Hence interest in these groups leads to imposing specific roles on them that they can fulfill in the political sphere.

Firstly, as political entities (participants of public politics), they can modify or trigger processes that are significant for the political system and society as a whole. Secondly, they are an anchor and a base for the political elite. Thirdly, they are a guarantee of the stability of political systems. Fourthly, they participate directly or indirectly in the process of making "strategic", tactical, and operational decisions. Fifthly, they shape the internal structure of power, assigning superior positions and roles to certain individuals or subgroups in making decisions (of internal and external nature), and create specific bonds, symbols, and rituals. ${ }^{24}$

All the aforementioned functions and resultant tasks are in line with the declared mission and goals, and are implemented by organizations from the non-governmental, non-commercial sector in the Russian Federation. The secondary position in this case is taken up by issues such as the bottom-up or top-down process of their establishing, founding institutions, sources of financing, and management of organization's assets as well as the area and profile of activity. By adjusting to the political realities of the Russian state, they assume the roles of state structures, often not only supporting, but $d e$ facto replacing or displacing them. In practice, they become contractors in the implementation of tasks in the context of fulfilling socially significant duties. This, in turn, confirms the thesis that it is necessary to maintain balance between the state, the business, and the non-commercial sectors since such a trialistic approach is the only one to not only guarantee stability but also determine the development of the state.

The last, quite important concept from the point of view of researching the particularities of Russian non-governmental sector is the theory of participation, which was diagnosed in terms of political participation. When analyzing the scope and levels of the political participation of citizens, the author indicated two forms of civil participation - anti-politics, which means questioning politics and "social self-defense" following the slogans of overcoming politics as such, and metapolitics, which means activity for social control and regulation of the conditions for practicing politics, observing the rules of political games and the rights of its participants, subordinating goals and policy measures to the superior moral standards, interests, and human values ${ }^{25}$. The list of civil

24 A. Chodubski, "Grup teoria”, in M. Żmigrodzki (ed.), Encyklopedia politologii, vol. 1: W. Sokół, M. Żmigrodzki (eds), Pojęcia, teorie i metody, Warszawa 2016, pp. 260-262.

25 M. Karwat, "Polityka rzeczowa, stronnicza i metapolityka", in T. Klementewicz (ed.), Wspótczesne teorie polityki - od logiki do retoryki, Warszawa 2004. 
forms of metapolitics can include the previously mentioned forms of civil disobedience (catalogued by Gene Sharp), but also bottom-up activities whose area of activity is not individual but general, and has deeply humanistic roots (e.g. human rights movements, metapolitical reflection of intellectuals, etc.). Institutional forms of metapolitics such as the Ombudsman, constitutional judicature, control function of the media, etc. ${ }^{26}$ were complemented by Russian policy-makers with vernacular solutions such as Social Chambers, social committees, and social councils operating at ministries, departments, and services at the federal, regional, and municipal levels. Institutional forms of participation include (apart from the non-governmental, non-commercial sector in Russia) the so-called "civil society institutions".

The phenomenon of the non-governmental, non-commercial sector in contemporary Russia necessitates using such theoretical approaches that will allow its exploration on a level sufficient to diagnose the social sector as well as the state and the commercial sectors. The thesis regarding trialistic provenance of the studied phenomenon in the conditions of a state that is transforming itself without a clearly defined vector of those changes, together with the systems analysis with its characteristic neo-institutional as well as neo-corporatist (neo-corporationist) approach, and with the conception of metapolitics combined with group theory, can be seen as an optimal tool to study the non-governmental, non-commercial sector in today's Russia. They are a suitable instrument to analyze transformations occurring in the inner sphere of life of the Russian society as well as that of the state; this in turn, by making it possible to retrace the changes, presents the image of a constantly changing political-social reality, also inviting a number of prognostic questions.

\section{BIBLIOGRAPHY}

Anheier H., Mertens S., "Sektor non profit w perspektywie międzynarodowej i europejskiej: dane, teoria i statystyka", in A. Gałązka, J. Herbst (eds.), Trzeci sektor dla zaawansowanych. Wspótczesne teorie trzeciego sektora. Wybór tekstów, transl. by J. Popowski, Warszawa 2006.

Antoszewski A., "System polityczny jako przedmiot badań politologii i nauki prawa konstytucyjnego", Wroctawskie Studia Erazmiańskie. Studia Erasmiana Wratislaviensia, vol. 8: Rozprawa o metodzie prawa i polityki. Discourse on the Methods of Law and Politics (2014).

Bauman Z., Ponowoczesność jako źródto cierpień, Warszawa 2000.

Chodubski A., "Grup teoria”, in M. Żmigrodzki (ed.), Encyklopedia politologii, vol. 1: W. Sokół, M. Żmigrodzki (eds.), Pojęcia, teorie i metody, Warszawa 2016.

Croucher R., Wood G., "Tripartism in Comparative and Historical Perspective", Business History, vol. 57, no. 3 (2015), https://doi.org/10.1080/00076791.2014.983479.

Dahl R.A., Stinebrickner B., Wspótczesna analiza polityczna, transl. by P.M. Kazimierczak, Warszawa 2007.

26 Idem, Uczestnictwo w polityce. Spoteczne ramy zjawiska, Pułtusk Academy of Humanities, Faculty of Political Science, academic year 2001/2002, winter/summer term, year 1, subject: Partycypacja $i$ animacja spoteczna [unpublished academic scripts for students]. 
Defourny J., Develtere P., “Ekonomia społeczna: ogólnoświatowy trzeci sektor”, in A. Gałązka, J. Herbst (eds.), Trzeci sektor dla zaawansowanych. Wspótczesne teorie trzeciego sektora. Wybór tekstów, transl. by J. Popowski, Warszawa 2006.

Douglas M., Czystość i zmaza. Analiza pojęć nieczystości i tabu, transl. by M. Bucholc, Warszawa 2007.

Gałązka A., Herbst J. (eds.), Trzeci sektor dla zaawansowanych. Wspótczesne teorie trzeciego sektora. Wybór tekstów, transl. by J. Popowski, Warszawa 2006.

Gumuła W., Teoria osobliwości spotecznych. Zaskakująca transformacja w Polsce, Warszawa 2008. Hall P.A., Taylor R.C.R., "Political Science and Three New Institutionalisms", Political Studies, vol. 44, no. 4 (1996), at <https://www.mpifg.de/pu/mpifg_dp/dp96-6.pdf>.

Jabłoński A.W., “Teoria i podejścia w badaniach zmiany systemów politycznych”, in B. KrauzMozer, P. Ścigaj (eds.), Podejścia badawcze i metodologie w nauce o polityce, Kraków 2013.

Jach A. (ed.), Rewolucja rosyjska. Spuścizna. "Implementacje strategii” zmiany, Kraków 2017.

Karwat M., "Polityka rzeczowa, stronnicza i metapolityka", in T. Klementewicz (ed.), Wspótczesne teorie polityki - od logiki do retoryki, Warszawa 2004.

Karwat M., Uczestnictwo w polityce. Spoteczne ramy zjawiska, Pułtusk Academy of Humanities, Faculty of Political Science, academic year 2001/2002, winter/summer term, year 1, subject: Partycypacja i animacja spoteczna [unpublished academic scripts for students].

Kisilowski M., Prawo sektora pozarzadowego. Analiza funkcjonalna, Warszawa 2009.

Kiviniemi M., "Conclusions. The State of Our Knowledge and Future Challenges", in S.P. Osborne (ed.), The Third Sector in Europe. Prospects and Challenges, London-New York 2008, https://doi.org/10.4324/9780203932827.

Klementewicz T. (ed.), Wspótczesne teorie polityki - od logiki do retoryki, Warszawa 2004.

Krauz-Mozer B., Ścigaj P. (eds.), Podejścia badawcze i metodologie w nauce o polityce, Kraków 2013. Łotman J., Uspienski B., “'Odszczepieniec' i 'odszczepieństwo' jako pozycje społecznopsychologiczne w kulturze rosyjskiej - na materiale z epoki przedpiotrowej ('Swoje' i 'obce' w historii kultury rosyjskiej)”, in B. Żyłko (ed.), Semiotyka dziejów Rosji, transl. by B. Żyłko, Łódź 1993.

March J.G., Olsen J.P., “The New Institutionalism: Organizational Factors in Political Life”, American Political Science Review, vol. 78, no. 3 (1984), https://doi.org/10.2307/1961840.

Nyssens M., "The Third Sector and the Social Inclusion Agenda. The Role of Social Enterprises in the Field of Work Integration", in S.P. Osborne (ed.), The Third Sector in Europe. Prospects and Challenges, London-New York 2008, https://doi.org/10.4324/9780203932827.

Osborne S.P. (ed.), The Third Sector in Europe. Prospects and Challenges, London-New York 2008, https://doi.org/10.4324/9780203932827.

Salamon L.M., Sokolowski W.S., List R., Global Civil Society. An Overview, Baltimore 2003.

Simon J.G., "Foreword", in D.R. Young, If Not for Profit, for What? A Behavioral Theory of the Nonprofit Sector Based on Entrepreneurship, Lexington 1983.

Skrzypek A., Druga smuta. Zarys dziejów Rosji 1985-2004, Warszawa 2004.

Skrzypek A., Putinada. Rosja - kraj kierowanej demokracji, Warszawa 2014.

Sungurow A., "Rosyjskie i radzieckie tradycje udziału przedstawicieli środowiska akademickiego w polityce. Władimir Wiernadski, Andriej Sacharow i inni”, in A. Jach (ed.), Rewolucja rosyjska. Spuścizna. "Implementacje strategii" zmiany, Kraków 2017. 
Sztompka P., Socjologia. Analiza spoteczeństwa, Kraków 2012.

Young D.R., If Not for Profit, for What? A Behavioral Theory of the Nonprofit Sector Based on Entrepreneurship, Lexington 1983.

Żmigrodzki M. (ed.), Encyklopedia politologii, vol. 1: W. Sokół, M. Żmigrodzki (eds.), Pojęcia, teorie i metody, Warszawa 2016.

Żyłko B. (ed.), Semiotyka dziejów Rosji, transl. by B. Żyłko, Łódź 1993.

“Выступцение на открытии Гражданского форума”, Президент России, 21 November 2001, at <http://kremlin.ru/events/president/transcripts/21408>.

Патрушев С.В. (ed.), Институщиональная политология. Современный институционализм и политическал трансформачия России, Москва 2006.

Сморгунов М.В. (еd.), Публичнал политика. Институть, цифрование, развитие, Москва 2018.

Сморгунов А.В., “Публичная политика как отрасль науки”, in idem (ed.), Публичнал политика. Институты, цифрование, развитие, Москва 2018.

Сунгуров А.Ю., “Публичная политика: основные направления исследований (мировой и российский опыт)", Публичная политика, no. 1 (2017).

Сунгуров А.Ю., Как возникают политические инновации: “фабрикимысли” и другие институты-медиаторыь, Москва 2015.

Сурков В.Ю., “Национализация будущего [парагрвфы рro суверенную демократию]”, in Сувереннал демократия. От идеи к доктрине. Сборник статей, Москва 2007.

ХАопин А.А., “Российский социум: границы общностей и парадоксы их институциональной интеграции”, in C.В. Патрушев (еd.), Институциональная политология. Современныцй институционализм и политическая трансформация России, Москва 2006.

Anna JACH - doctor of political science, historian, assistant professor at the Chair of Eurasian Area Studies in the Institute of Russian and East European Studies at the Faculty of International and Political Studies of the Jagiellonian University in Kraków. She specializes in the history of the $20^{\text {th }}$ and $21^{\text {st }}$ centuries, particularly the history of the USSR and Russia, Polish-Russian relations, political system transformation as well as the functioning of the non-governmental, non-commercial sector, i.e. the third sector in Russia. 